\title{
Effect of phosphorus levels and bio-organic sources on growth and yield of rice (Oryza sativa L.)
}

\author{
R.K. MEENA, M.P. NEUPANE* AND S.P. SINGH \\ Department of Agronomy, Institute of Agricultural Sciences, Banaras Hindu University, VARANASI (U.P.) INDIA \\ (Email : mpneupane66@gmail.com)
}

\begin{abstract}
A field experiment was conducted during rainy season of 2013 at Agricultural Research Farm, Institute of Agricultural Sciences, Banaras Hindu University, Varanasi to evaluate the effect of phosphorus levels and bio-organic sources on growth and yield of wetland rice cv. HUR-105. Factorial experiment was laid out in Randomized Complete Block Design involving four levels of phosphorus viz., control, 50 per cent RDP, 75 per cent RDP and 100 per cent RDP and three bio-organic sources i.e. PSB, PSB $+\mathrm{BGA}$ and PSB + BGA + FYM $\left(5 \mathrm{tha}^{-1}\right)$ replicated thrice. Increase in the levels of phosphorus application upto 100 per cent RDP $\left(60 \mathrm{~kg} \mathrm{P}_{2} \mathrm{O}_{5} \mathrm{ha}^{-1}\right)$ improved growth attributes, yield attributes, grain and straw yields. Combined use of PSB + BGA + FYM (5 tha$\left.{ }^{1}\right)$ proved superior to PSB alone and PSB + BGA. Economic analysis indicated that integration of moderate phosphorus level (75\% RDP i.e. $\left.45 \mathrm{~kg} \mathrm{ha}^{-1}\right)$ along with the use of PSB $+\mathrm{BGA}+\mathrm{FYM}\left(5 \mathrm{t} \mathrm{ha}^{-1}\right)$ gave highest net return and $\mathrm{B}: \mathrm{C}$ ratio.
\end{abstract}

Key Words : Phosphorus levels, Bio-organics, FYM, BGA, PSB, Rice

View Point Article : Meena, R.K., Neupane, M.P. and Singh, S.P. (2015). Effect of phosphorus levels and bio-organic sources on growth and yield of rice (Oryza sativa L.). Internat. J. agric. Sci., 11 (2) : 286-289.

Article History : Received : 22.11.2014; Revised : 21.05.2015; Accepted : 28.05.2015

\footnotetext{
* Author for correspondence (Present Address) : Tribhuwan University, Institute of Agriculture and Animal Sciences, Lamjung Campus, LAMJUNG (NEPAL)
} 